\title{
VIDEO REFERENSI SEBAGAI SOLUSI PEMBELAJARAN ANIMASI 3D DI TENGAH PANDEMI COVID-19
}

\author{
Nina Tri Daniati \\ SMK Negeri 3 Kasihan \\ ninadaniati7297@gmail.com
}

\begin{abstract}
Abstrak: Peningkatan jumlah kasus positif di Indonesia akibat wabah Virus Corona Disease 2019 (Covid-19) membuat pemerintah menerapkan social distancing atau menjaga jarak interaksi sosial untuk mencegah dan meminimalisir penyebaran virus ini. Dalam bidang pendidikan, salah satu solusi yang ditawarkan adalah melakukan pembelajaran secara digital atau daring yang berbasis IT. Namun di SMK Negeri 3 Kasihan Bantul khususnya di kelas XI Program Studi Animasi, masih banyak terdapat siswa yang kesulitan dalam membuat gerakan animasi yang realistik. Ditengah kondisi pandemi covid-19 ini sangat sulit bagi siswa untuk belajar gerak animasi tanpa bimbingan dari guru. Oleh sebab itu untuk siswa yang masih dalam tahapan belajar ini, untuk menghasilkan gerak Animasi 3D yang memiliki kesan realistik membutuhkan media belajar yang dapat digunakan sebagai referensi. Salah satu referensi yang dapat digunakan sebagai media belajar adalah berupa rekaman video. Pembelajaran dengan cara ini meliputi 8 langkah, yakni: (a) Membuat perangkat pembelajaran; (b) Menyampaikan kegiatan pembelajaran; (c) Membuat video referensi secara mandiri; (d) Guru mengevaluasi hasil shoot video referensi; (e) Menggunakan video sebagai referensi dalam membuat gerak animasi; (f) Siswa me-render hasil karyanya; (g) Siswa mempresentasikan hasil karyanya; (h) Guru mereview hasil karya siswa. Hasil penerapan video referensi sebagai solusi pembelajaran animasi di tengah pandemi covid-19 sebagai berikut: (a) Hasil karya siswa yang berupa gerakan animasi bouncing ball menjadi lebih realistik dan mendekati gerak objek sesungguhnya; (b) Siswa mampu menyerap materi pembelajaran dengan baik meskipun tanpa pembelajaran dengan tatap muka secara langsung dengan guru.
\end{abstract}

Kata kunci: Covid-19, pembelajaran daring, video referensi, animasi bola pantul

\section{REFERENCE VIDEOS AS 3D ANIMATION LEARNING SOLUTIONS IN COVID-19 PANDEMICS}

\begin{abstract}
The increase in positive cases in Indonesia due to the 2019 Corona Disease Virus (Covid-19) has made the government implement social distancing to prevent and minimize the spread of the virus. In education, one of the solutions offered is to do digital or online learning based on IT. But in SMK Negeri 3 Kasihan Bantul especially in class XI Animation program, there are still many students who have difficulty in making realistic animations. Amid the covid-19 pandemic conditions, it is very difficult for students to learn animation without guidance from the teacher. Therefore for students who are still in this learning phase, to produce realistic 3D animations requires learning media that can be used as a reference. One appropriate reference is in the form of a video record. Learning in this way includes 8 steps: (a) Making a learning plan; (b) Delivering learning activities; (c) Making reference videos independently; $(d)$ The teacher evaluates the results of the reference video shoot; (e) Using video as a reference in making animations; (f) Students render their work, $(g)$ Students present their work; $(h)$ The teacher reviews the work of students. The result of applying reference videos as an animated learning solution in the midst of the covid-19 pandemic: (a) The bounce-ball animation of student's work becomes more realistic and approaches the motion of the real object; (b) Students are able to absorb learning material well even without face to face with the teacher.

Keywords: Covid-19, distance learning, reference videos, bounce-ball animation

\section{PENDAHULUAN}

Akibat peningkatan jumlah kasus positif di Indonesia akibat wabah Virus Corona Disease 2019 (Covid-19) membuat pemerintah melakukan berbagai upaya untuk mencegah dan meminimalisir penyebaran virus ini. Pemerintah menanggapi pandemi Covid-19 ini

dengan mengambil kebijakan dengan menerapkan social distancing atau menjaga jarak interaksi sosial. Hal ini diatur dalam UU No. 6 Tahun 2018 tentang Karantina Kesehatan yang kemudian dipertegas dengan PP No. 21 Tahun 2020 dan Permenkes 9 Tahun 2020 tentang Pembatasan Sosial Berskala Besar
\end{abstract}


(PSBB). Kebijakan tersebut bertujuan untuk mengantisipasi meluasnya penyebaran Virus Covid-19 dan sebagai upaya untuk memutus mata rantai penyebaran Virus Covid-19. Akibatnya, kebijakan sebagai upaya preventif tersebut memiliki berbagai dampak diberbagai bidang, karena dengan adanya kebijakan pembatasan pergerakan setiap orang di luar rumah dan berkumpul dalam jumlah banyak maka diberlakukan Work From Home (WFH) atau bekerja dari rumah bagi para pegawai dan belajar dari rumah bagi para siswa, maupun ibadah dari rumah bagi seluruh masyarakat. Hal tersebut tentunya memicu perubahan dalam dunia pendidikan terutama dalam strategi dan metode pembelajaran di kelas. Salah satu solusi yang ditawarkan adalah melakukan pembelajaran secara digital atau daring yang berbasis IT.

Pembelajaran secara daring merupakan pembelajaran jarak jauh dengan menggunakan perangkat komputer atau gatget yang memungkinkan guru dan siswa berkomunikasi secara interaktif dengan memanfaatkan jaringan internet. Aplikasi-aplikasi pembelajaran online sudah sangat canggih, mulai dari fasilitas virtual class dari G-Suite yaitu Google Classroom, Edmodo, Webex, Office 365, dan lain sebagainya.

Walaupun pembelajaran daring ini sudah cukup popular sejak lebih dari 1 dekade dan saat ini metode pembelajaran daring didorong sebagai respon terhadap Revolusi Industri 4.0. Akan tetapi iklim pendidikan di Indonesia masih belum sesuai pada perkembangan ini, metode ini belum banyak digunakan di dalam sistem pendidikan di Indonesia khususnya tingkat sekolah dasar hingga menengah. Masih banyak guru yang memiliki pengetahuan yang terbatas mengenai metode dan teknisnya. Pengetahuan dan pengalaman guru tentang aplikasi pembelajaran secara digital pun masih sangat kurang. Sehingga tidak semua guru siap mengoperasikan sistem pembelajaran daring dengan cepat, termasuk juga mempersiapkan bahan ajar secara digital. Namun demikian aktivitas pembelajaran antara pendidik dan siswa harus tetap dilaksanakan, sehingga kehadiran Covid-19 ini seolah-olah memaksa guru terbiasa dengan pola pembelajaran daring.

Demikian pula dengan siswa, mereka pun masih belum familiar dengan pembelajaran daring. Hal tersebut menjadi tantangan dan hambatan tersendiri bagi guru untuk melaksanakan pembelajaran daring. Akibatnya pembelajaran daring hanya berakhir pada pemberian tugas secara jarak jauh tanpa ada umpan balik maupun interaksi dengan siswa.

Oleh sebab itu guru dituntut untuk mampu merancang dan mendesain pembelajaran daring yang ringan dan efektif, dengan memanfaatkan perangkat yang tepat sesuai dengan materi yang diajarkan, sehingga tujuan awal dari pelaksanaan pembelajaran daring yaitu untuk mempermudah siswa mendapatkan pembelajaran atau pendidikan dalam situasi pandemi covid-19 ini dapat tercapai.

Pembelajaran daring memberikan kesempatan lebih luas dalam mengeksplorasi materi yang akan diajarkan, namun guru harus mampu memilih cakupan materi yang metode yang cocok digunakan. Metode pembelajaran yang tepat adalah metode mengajar yang membangun kemandirian siswa dalam belajar. Sehingga guru lebih memfokuskan diri pada upaya transfer pengetahuan dan keterampilan kepada siswa. Hal tersebut juga bisa mendorong siswa agar bisa lebih inovatif dan kreatif dalam belajar (student learning center). Salah satu metode pembelajaran yang membangun kemandirian belajar anak adalah membimbing siswa membuat media pembelajaran bagi dirinya sendiri.

Pembelajaran Animasi 3D di Sekolah Menengah Kejuruan (SMK) menerapkan kurikulum 2013 sebagai acuan dalam menyusun perencanaan dan materi ajar. Pembelajaran tersebut terdiri atas tiga kompetensi yakni kemampuan membuat model (modelling), kemampuan membuat kerangka (rigging), dan kemampuan menggerakkan (animating).

Seorang animator harus memiliki kemampuan meng-capture momentum ke dalam urutan gambar sehingga seolah-olah menjadi hidup. Sedangkan di SMK Negeri 3 Kasihan Bantul khususnya kelas XI Animasi masih banyak terdapat siswa yang kesulitan dalam membuat gerakan animasi yang realistik. Hal tersebut dapat dilihat bahwa banyak siswa tidak mengalami ketuntasan dalam hasil belajar yaitu untuk nilai keterampilan dengan tingkat ketuntasan 33\% dengan nilai rata-rata 62,74. Ditengah kondisi pandemi covid-19 ini sangat sulit bagi siswa untuk belajar gerak animasi tanpa bimbingan dari guru. Oleh sebab itu untuk siswa yang masih dalam tahapan belajar ini, untuk menghasilkan gerak Animasi 3D yang memiliki kesan realistik membutuhkan media belajar yang dapat digunakan sebagai 
referensi. Salah satu referensi yang dapat digunakan sebagai media belajar adalah berupa rekaman video. Aspek penting penggunaan media video adalah video dapat menyajikan gerakan objek yang sesungguhnya dan yang dapat digunakan secara berulang-ulang sebagai panduan sehingga sangat membantu dalam memperjelas materi yang sedang dipelajari. Penggunaan media video dapat merangsang pengetahuan siswa, melatih berpikir logis, analistik, lebih kreatif, efektif dan mempertajam daya imajinasi siswa.

Salah satu materi gerak animasi dasar adalah membuat gerak bounching ball. Untuk membuat gerakan bounching ball yang realistik siswa terlebih dahulu membuat video referensi. Berbekal kamera Handphone, siswa diberikan kesempatan untuk mempraktekkan melempar berbagai jenis sport balls, kemudian mengamati pergerakannya, dan membandingkan lentingan bola satu dengan bola lainnya, kemudian mendokumentasikan kegiatannya dan menggunakan sebagai video referensi dalam membuat animasi bounching ball. Dengan pemanfaatan video referensi ini diharapkan mampu memperjelas materi yang disampaikan guru melalui pembelajaran daring, utamanya dalam keterampilan membuat animasi.

\section{TINJAUAN PUSTAKA \\ Media Pembelajaran}

Secara harfiah, kata media berasal dari bahasa latin medium yang memiliki arti "perantara" atau "pengantar". Gerlach \& Ely, mengatakan bahwa media apabila dipahami secara garis besar adalah manusia, materi, atau kejadian yang membangun kondisi yang membuat siswa mampu memperoleh pengetahuan, keterampilan, atau sikap. Secara khusus, pengertian media dalam proses belajar mengajar cenderung diartikan sebagai alat-alat grafis, photografis, atau elektronik untuk menangkap, memproses, dan menyusun kembali informasi visual atau verbal (Arsyad, 2002:3). Gagne menyatakan bahwa media adalah berbagai jenis komponen dalam lingkungan siswa yang dapat merangsangnya untuk belajar, sementara itu Briggs berpendapat bahwa media adalah segala alat fisik yang dapat menyajikan pesan serta merangsang siswa untuk belajar (Arif $\mathrm{S}$. Sadiman, 2003:6). Adapun media pengajaran menurut Ibrahim dan Syaodih (2003:112) diartikan sebagai segala sesuatu yang dapat digunakan untuk menyalurkan pesan atau isi pelajaran, merangsang pikiran, perasaan, perhatian dan kemampuan siswa, sehingga dapat mendorong proses belajar mengajar. Dari berbagai definisi di atas dapat diambil kesimpulan bahwa media adalah segala benda yang dapat menyalurkan pesan atau isi pelajaran sehingga dapat merangsang siswa untuk belajar.

\section{Media Video}

Media pembelajaran video adalah alat yang digunakan untuk menyampaikan materi pembelajaran melalui tayangan gambar bergerak yang diproyeksikan membentuk karakter yang sama dengan obyek aslinya. Video merupakan salah satu media yang banyak dikembangkan untuk keperluan pembelajaran karena dapat meningkatkan hasil pembelajaran. Penggunaan media pembelajaran video mampu memberikan respons positif dari siswa. Siswa termotivasi untuk belajar dan mampu meningkatkan pemahamannya terhadap materi pelajaran yang disampaikan (Fechera, Maman dan Dadang, 2012).

Kemudian pendapat dari Daryanto (2010:90) mengatakan bahwa "Video merupakan bahan ajar non cetak yang kaya informasi dan lugas karena dapat sampai di hadapan siswa secara langsung, video menambah suatu dimensi baru terhadap pembelajaran". Selanjutnya pendapat dari Ahmad (2007:4) bahwa: "Guru dan media pendidikan hendaknya bahu-membahu dalam memberikan kemudahan belajar bagi siswa. Perhatian dan bimbingan secara individual dapat dilaksanakan oleh guru dengan baik, sementara informasi dapat pula disajikan secara jelas, menarik dan teliti oleh media pendidikan".

Video dapat memberikan model yang lebih realistis kepada siswa sehingga siswa dapat berperan aktif dalam pembelajaran. Selain itu, dapat mempermudah pembelajaran bahasa karena disertai penguatan visual langsung, sehingga dari apa yang mereka dengar dan mereka lihat bisa menuangkannya ke dalam bentuk animasi.

Manfaat media video menurut Aqib (2013:51) antara lain: 1) Pembelajaran lebih jelas dan menarik; 2) proses belajar lebih interaksi; 3) efisiensi waktu dan tenaga; 4) meningkatkan kualitas hasil belajar; 5) belajar dapat dilakukan dimana dan kapan saja; 6) 
menumbuhkan sikap positif belajar terhadap proses dan materi belajar; 7) meningkatkan peran guru ke arah yang lebih positif dan produktif".

Selanjutnya kelebihan media video menurut Rusman (2012:220) yaitu: 1) video dapat memberikan pesan yang dapat diterima lebih merata oleh siswa; 2) video sangat bagus untuk menerangkan suatu proses; 3 ) mengatasi keterbatasan ruang dan waktu, lebih realistis dan dapat diulang atau dihentikan sesuai kebutuhan, serta; 4) memberikan kesan yang mendalam, yang dapat mempengaruhi sikap siswa".

Beberapa pendapat di atas dapat disimpulkan bahwa dengan adanya proses pembelajaran yang menggunakan media video, siswa dapat mengefisienkan waktu dalam belajar, memberikan pengalaman yang baru kepada siswa, dan memberikan informasi yang akurat, dan real.

\section{Animasi Bouncing Ball}

Menurut R Yunanta (2017) bouncing ball atau bola memantul adalah salah satu materi pembelajaran gerak animasi dasar. Bouncing ball juga merupakan sebuah latihan yang paling terkenal dan biasa dilakukan oleh para animator pemula, pada latihan bola memantul akan ada banyak kasus yang dapat dipelajari untuk diterapkan pada proses pembuatan animasi.
Bouncing ball digunakan sebagai latihan animasi karena ada banyak prinsip penting dalam proses pembuatannya. Dalam bentuk yang paling sederhana latihan ini mengajarkan tentang dasar timing (waktu), spacing (jarak), weight (berat), arc, squash and stretch, appeal (gaya visual animasi).

Berikut ini beberapa alasan mengapa bouncing ball sangat wajib untuk dikuasai, seperti yang dikutip oleh animator dunia Ray Chase:

1. Melatih kepekaan terhadap timing (waktu) dan spacing (jarak). Timing dan spacing akan menjadi dasar yang kuat untuk mendapatkan bola pantul yang terlihat alami.

2. Meningkatkan pemahaman tentang arc, ease in dan ease out.

\section{HASIL DAN PEMBAHASAN Metode Penelitian}

Studi ini merupakan penelitian praktik baik (best practice). Berdasarkan latar belakang yang diuraikan di atas, maka dapat dirumuskan permasalahan sebagai berikut: "Apakah pembuatan dan penggunaan video referensi dapat digunakan sebagai solusi pembelajaran Animasi 3D di tengah pandemi Covid-19?"

Kerangka berpikir pada kegiatan ini dapat dilihat pada bagan berikut ini:
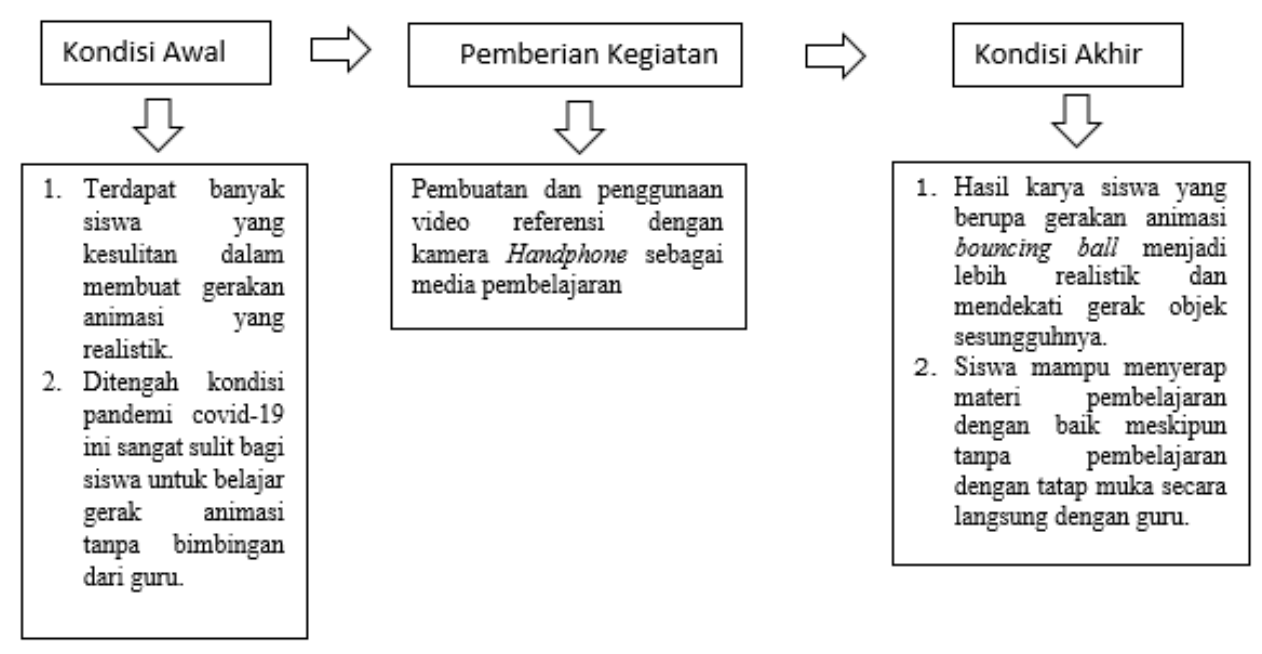

Gambar 1. Kerangka berpikir

Berdasarkan kerangka berikir di atas, maka hipotesis penulisan best practice ini adalah: "Pembuatan dan penggunaan video referensi menjadi solusi pembelajaran Animasi 3D di tengah pandemi Covid-19".

\section{Strategi Pemecahan Masalah}

1. Deskripsi strategi pemecahan masalah yang dipilih

Strategi pemecahan masalah rendahnya keterampilan membuat gerak Animasi 3D yang harus belajar tanpa bimbingan dari guru dengan tatap muka secara langsung adalah dengan 
membuat rekaman video gerakan objek sesungguhnya sebagai referensi untuk membuat gerakan Animasi 3D dengan kamera Handphone.

Ada beberapa alasan mengapa penulis memilih menggunakan pembuatan video referensi sebagai solusi untuk pembelajaran animasi di tengah pandemi covid-19 di kelas XI Animasi SMK Negeri 3 Kasihan, diantaranya yaitu:

a. Siswa mendapatkan pengalaman yang lebih nyata dengan mempraktikkan gerakan secara langsung, kemudian mengamati dan mendokumentasikannya. Sehingga siswa akan lebih menjiwai pada saat mengaplikasikan gerakan tersebut ke dalam bentuk digital.

b. Video dapat menyajikan gerakan objek yang sesungguhnya sehingga dapat mengajarkan bagaimana membuat gerakan yang lebih realistik

c. Video dapat diputar secara berulang-ulang sehingga sangat baik untuk digunakan sebagai panduan belajar

d. Membuat suasana belajar yang lebih menyenangkan, karena pembelajaran menjadi lebih variatif, tidak terus-menerus fokus di depan komputer.

e. Seluruh siswa di kelas XI Animasi SMK Negeri 3 Kasihan telah memiliki handphone yang memiliki fitur yang cukup untuk membuat video sederhana.
2. Penjelasan tahapan operasional pelaksanaan Pembuatan video referensi ini diterapkan pada pembelajaran Animasi 3D dengan materi membuat animasi bouncing ball pada kelas XI Animasi semester Genap.

Siswa diberikan kesempatan untuk mempraktikkan melempar bola, kemudian mengamati pergerakannya, dan membandingkan lentingan bola yang satu dengan lainnya kemudian mendokumentasikan kegiatannya dan mengkonsultasikan hasil rekamannya kepada guru baik melalui Google Classroom maupun Whatsapp chat, lalu menggunakan sebagai video referensi dalam membuat animasi bouncing ball. Sehingga siswa akan memperoleh pengalaman dan pemahaman yang lebih realistik.

\section{Pelaksanaan}

Untuk mengimplementasikan pembuatan dan penggunaan video referensi sebagai solusi pembelajaran animasi di tengah pandemi covid-19 di kelas XI Animasi, penulis mendeskripsikannya dalam Rencana Pelaksanaan Pembelajaran di Kelas XI Animasi dengan menjelaskan apa yang akan dikerjakan dalam beberapa pertemuan. Kemudian menjelaskan tujuan pembelajaran akan membuat siswa termotivasi mengikuti kegiatan pembelajaran dengan materi pembuatan gerak animasi.

Kegiatan pembelajaran dilaksanakan dalam 8 tahap sebagai berikut:

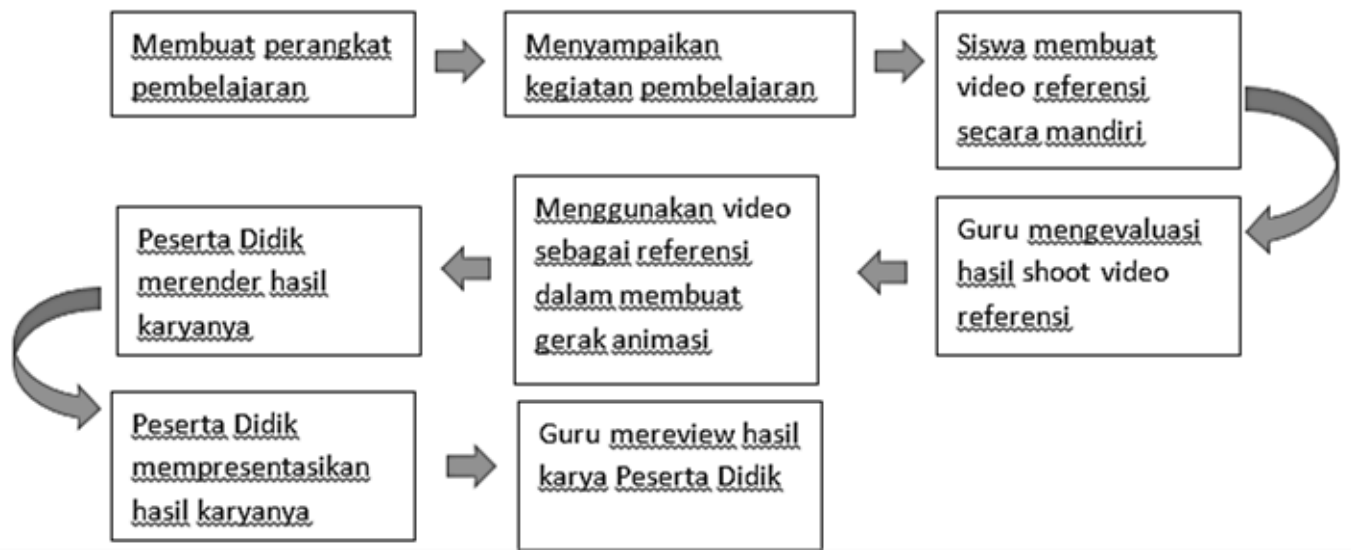

Gambar 2. Tahapan kegiatan pembelajaran

\section{Keterangan:}

1) Membuat perangkat pembelajaran. Perangkat pembelajaran yang dibuat yaitu silabus, Rencana Pelaksanaan Pembelajaran (RPP), job sheet.

Topik pembelajaran yang diangkat pada penelitian ini adalah materi bola pantul (bouncing ball), yaitu materi pembelajaran kelas XI Animasi KD keterampilan 4.9. Membuat animasi bola pantul sesuai dengan 12 prinsip animasi.

2) Menyampaikan kegiatan pembelajaran yang diawali dengan menjelaskan tujuan pembelajaran dan kegiatan pembelajaran yang akan dilakukan melalui Google Classroom. 
3) Siswa membuat video referensi secara mandiri.

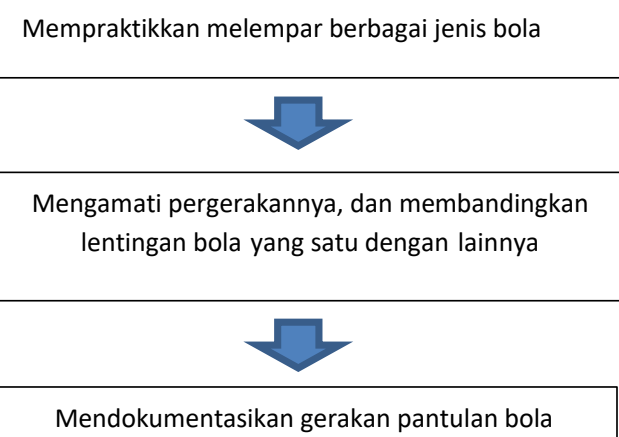

Gambar 3. Kegiatan siswa

4) Guru mengevaluasi hasil shoot video referensi.

Siswa mengirimkan file hasil shoot video referensi melalui Google Classroom maupun Whatsapp chat, kemudian guru memberikan koreksi/ masukan, agar pembelajaran tetap dapat berjalan secara kondusif dan hasil rekaman video sesuai yang diharapkan, sehingga hasil rekaman video dapat digunakan sebagai referensi belajar.

5) Menggunakan video sebagai referensi dalam membuat gerak animasi.

Siswa menggunakan video sebagai referensi yang telah dikoreksi oleh guru untuk membuat gerak animasi bouncing ball.

6) Siswa merender hasil karyanya.

7) Siswa mempresentasikan hasil karyanya.

Siswa mempresentasikan hasil karyanya dengan mengirimkan hasil render kepada guru melalui Google Classroom.

8) Guru mereview hasil karya Siswa.

\section{Hasil Yang Dicapai}

Hasil yang diperoleh dari penerapan pembuatan dan penggunaan video referensi sebagai solusi pembelajaran animasi di tengah pandemi covid-19 di kelas XI Animasi adalah:

1. Hasil karya siswa yang berupa gerakan animasi bouncing ball menjadi lebih realistik dan mendekati gerak objek sesungguhnya.

2. Siswa mampu menyerap materi pembelajaran dengan baik meskipun tanpa pembelajaran dengan tatap muka secara langsung dengan guru. Hal ini dapat dibuktikan dengan meningkatnya nilai keterampilan dengan tingkat ketuntasan $64 \%$ dengan nilai rata-rata 76 .

\section{Manfaat Best Practice Yang Dilaksanakan}

Manfaat dari pembuatan dan penggunaan video referensi sebagai solusi pembelajaran animasi di tengah pandemi covid-19 sebagai berikut:

1. Siswa bisa memanfaatkan gadgetnya untuk mendukung peningkatan kompetensinya.

2. Meningkatnya kemandirian siswa dalam proses belajar.

3. Melatih siswa berpikir logis, konkrit, lebih realistis, kemudian proses belajar lebih aktif, kreatif, dan berkesan.

4. Membuat suasana belajar di rumah menjadi lebih menyenangkan, karena pembelajaran menjadi lebih variatif, tidak terus-menerus fokus di depan komputer.

5. Dengan siswa mencoba mempraktekkan melempar bola secara langsung, kemudian mengamati dan mendokumentasikannya, siswa mendapatkan pengalaman yang lebih nyata, sehingga siswa akan lebih menjiwai pada saat mengaplikasikan gerakan tersebut ke dalam bentuk digital.

6. Video dapat diputar secara berulang-ulang, hal ini memberikan kesan yang mendalam bagi siswa, yang dapat mempengaruhi kemampuan siswa dalam mengerjakan tugas.

7. Video mengatasi keterbatasan ruang dan waktu sehingga sangat efektif untuk menunjang sistem pembelajaran daring pada mata pelajaran Animasi 3D materi pembuatan gerak animasi bouncing ball.

\section{Tindak Lanjut Best Practice}

Tindak lanjut pengembangan pembuatan dan penggunaan video referensi sebagai solusi pembelajaran animasi di tengah pandemi covid-19 di kelas XI Animasi SMK Negeri 3 Kasihan adalah:

1. Penerapan pada materi mata pelajaran Animasi 3D yang lain, seperti walk cycle, run cycle dan jump action.

2. Penerapan pada mata pelajaran yang lain seperti Animasi 2 Dimensi.

3. Metode ini dapat menjadi alternatif pembelajaran bagi siswa inklusi baik pada pembelajaran daring maupun tatap muka secara langsung.

\section{SIMPULAN DAN SARAN}

Pembuatan dan penggunaan video referensi yang digunakan sebagai solusi pembelajaran Animasi 3D di tengah pandemi covid-19 di kelas XI Animasi terbukti dapat 
meningkatkan keterampilan siswa dalam materi pembuatan gerak animasi khususnya animasi bouncing ball meskipun tanpa bimbingan guru dengan tatap muka secara langsung.

Dengan memberi kesempatan siswa untuk mempraktikkan melempar bola, kemudian mengamati pergerakannya, dan membandingkan lentingan bola yang satu dengan lainnya, siswa kemudian mendokumentasikan kegiatannya, dan mengkonsultasikan hasil rekamannya kepada guru baik melalui Google Classroom maupun Whatsapp chat, lalu menggunakan sebagai video referensi dalam membuat animasi bouncing ball. Sehingga siswa akan memperoleh pengalaman dan pemahaman yang lebih realistik.

Selain itu kegiatan pembelajaran yang lebih berpusat kepada aktivitas siswa (student learning center) akan melatih kemandirian siswa dalam proses belajar.

Berkaitan dengan simpulan di atas, dapat disampaikan beberapa saran berikut:

1. Dalam pelaksanaan guru mengajarkan mata pelajaran praktik dengan sistem daring hendaknya selalu berusaha mencari variasi model belajar yang memberi ruang bagi terbukanya keaktifan siswa dan ketrampilan proses siswa. Dengan variasi model belajar niscaya hasil belajar siswa pun juga akan mencapai ketuntasan dan hasil karya yang memuaskan.

2. Siswa hendaknya harus aktif dalam proses pembelajaran, dengan mengambil fakta yang terjadi di dalam kehidupan seharihari akan diperoleh konsep yang benarbenar mendalam.

\section{DAFTAR PUSTAKA}

Ahmad, A. K. H. (2007). Media Pembelajaran. Makassar: Badan Penerbit Universitas negeri Makassar.

Anonim. Catatan Untuk Dunia Pendidikan di Era Revolusi industri 4.0. Diakses tanggal 18 April 2020 dari https://www.asikbelajar.com/catatanuntuk-dunia-pendidikan-di-era-revolusiindustri-4-0/

Aqib, Z. (2013). Model-model, Media, dan Strategi Pembelajaran Kontekstual (Inovatif). Bandung: Yrama Widya.
Arief, S. S. (2003). Media Pendidikan. Jakarta: Raja Grafindo Persada.

Arsyad, A. (2002). Media Pembelajaran. Jakarta: Raja Grafindo.

Daryanto. (2010). Media Pembelajaran. Yogyakarta: Gava media.

Fechera, B. Somantri, M. dan Dadang. (2012). Desain Dan Implementasi Media Pembelajaran menggunakan Video Prinsip-Prinsip Alat Ukur Listrik Dan Elektronika. Diakses tanggal 16 April 2020 dari https://ejournal.upi.edu/index. php/invotec/article/view/6125

Ibrahim, R. dan Syaodih, N. (2003). Perencanaan Pengajaran. Jakarta: Rineka Cipta.

Kementrian Kesehatan Republik Indonesia. Kesiapsiagaan Menghadapi Novel Coronavirus. Diakses tanggal 16 April 2020 dari https://www.kemkes.go.id/ article/view/20012900002/Kesiapsiagaan -menghadapi-Infeksi-NovelCoronavirus.html

Riyatna, C. (2007). Pedoman Pengembangan Media Video. Bandung: P3AI Universitas Pendidikan Indonesia

Rusman. (2012). Model-Model Pembelajaran. Depok: PT Raja Grafindo Persada

Silberman, M. (2009). Active Learning. 101 Strategi Pembelajaran Aktif. Yogyakarta: Pustaka Insan Madani.

Sukiman. (2012). Pengembangan Media Pembelajaran. Yogyakarta: Pedagogia

Suyanto, A.H. (2005). Mengenal E-Learning. Diakses tanggal 18 April 2020 dari https://www.asikbelajar.com/catatanuntuk-dunia-pendidikan-di-era-revolusiindustri-4-0/

The Conversation. Kesenjangan akses internet di Asia Tenggara jadi tantangan bagi pengajaran online akibat pandemi COVID-19. Diakses tanggal 16 April 2020 dari https://theconversation. com/kesenjangan-akses-internet-di-asiatenggara-jadi-tantangan-bagi-pengajaranonline-akibat-pandemi-covid-19-133928,

Yunanta, R. (2017). Animasi Bola Memantul. Diakses tanggal 12 Maret 2020 dari https://repository.unikom.ac.id/51217/1/A nimasi\%20Bola\%20Memantul.pdf 